\title{
Efektivitas Diabetes Self Management Education \& Community Based Interactive Approach Terhadap Self Care Penderita Diabetes Mellitus
}

\author{
Diani Novianti ${ }^{1}$, Nina Indriyawati ${ }^{2}$, Syamsul Arif $^{2}$ \\ ${ }^{1}$ Mahasiswa Program Studi S1 Terapan Poltekkes Kemenkes Semarang \\ ${ }^{2}$ Dosen Jurusan Keperawatan Poltekkes Kemenkes Semarang \\ Corresponding author: noviantidiani313@gmail.com
}

\begin{abstract}
Background: Self care deficit is still a major problem in patients with type 2 diabetes mellitus because self care agency is lower than self care demands, where it can be influenced by several factors, one of which is knowledge.

Purpose: This study aims to determine the effectiveness of DSME and CBIA-DM on self care in people with diabetes mellitus.

Methods: The research method was quasy prepost test design. Sample of the study was diabetes mellitus type 2 patients $(n=52)$ divided into 2 groups using non probability sampling with purposive sampling. The instrument used SDSCA questionnaire by Kusniawati (2011) ( $r=0,361$, alpha cronbach ' $s=0,80)$. Data analysis used dependent and independent $t$ test.

Results: Data analysis used independent t test obtained $\mathrm{p}$ value 0.019 , indicating there was a significant differences and the results of the $\triangle$ mean DSME group was 18,50 and the $\Delta$ mean CBIA-DM group was 15.61 , so that DSME was more effective than CBIADM.

Conclusion: DSME is more effective to improving self care in people with diabetes mellitus. It is recommended that the Puskesmas can implement the DSME intervention conducting socialization through prolanist activities.
\end{abstract}

\section{Keywords:}

Diabetes Mellitus; DSME; CBIA-DM; Self Care; self care deficit

\section{LATAR BELAKANG}

Diabetes Mellitus adalah suatu gangguan metabolisme glukosa yang mengakibatkan permasalahan pada kontrol glukosa sehingga kadar gula darah menjadi tinggi (Prihaningtyas, 2013). Berdasarkan data dari International Diabetes Federation (IDF) tahun 2015, didapatkan hasil prevalensi penderita diabetes mellitus di Indonesia menempati peringkat ketujuh di dunia dengan penderita DM sebesar 10 juta jiwa. 
Penderita diabetes mellitus harus dapat mengelola dan merawat dirinya dengan baik untuk mencegah komplikasi (Suhanda, 2015). Hal tersebut dapat diatasi jika penderita memiliki pengetahuan dan kemampuan dalam melakukan self care (Suhanda, 2015). Self care dapat mencegah terjadinya angka kesakitan bahkan angka kematian serta komplikasi jangka panjang dari DM, hal ini dapat dilakukan jika penderita memiliki perilaku self care yang baik (Shrivastava, 2013). Selain itu self care merupakan poin penting dalam pengelolaan atau self management (Bradshaw, 2015).

Meskipun self care memiliki peranan yang penting dalam pencegahan dan pengelolaan DM tetapi mayoritas penderita DM masih memiliki tingkat self care yang rendah. Oleh karena itu diperlukan peningkatan pengetahuan mengenai self care. Praktik self care sebaiknya dikembangkan dan diintegrasikan dalam diabetes self care education (Raithatha, 2014). Perilaku self care memiliki peran penting untuk pencegahan komplikasi jangka pendek dan jangka panjang sehingga sangat diperlukan program edukasi agar pengobatan DM dapat berjalan dengan baik (Karimi, 2017). Metode Edukasi yang baik dan terintegrasikan secara tepat akan mempengaruhi perilaku self care dan kadar gula darah (Zandinava, 2017).

Salah satu metode edukasi yang dapat dilakukan adalah Diabetes Self Management Education (DSME). DSME adalah suatu cara yang mengajarkan pengetahuan dan kterampilan secara terus menerus atau berkelanjutan tentang pengelolaan DM (Rahmawati, 2016). DSME adalah suatu metode yang berisi pendidikan kesehatan dimana didalamnya terdapat pengetahuan, keterampilan, kemampuan self care dan self efficacy yang bertujuan untuk mengelola penyakit DM (Rondhianto, 2012).

Selain DSME, metode edukasi yang efektif yang dalam meningkatkan self care adalah Community Based Interactive Approach (CBIA). CBIA adalah metode diskusi kelompok dimana peserta yang aktif dalam jalannya diskusi (Hartayu et al, 2012 dan Lathifah, 2015). Namun didalam perkembangan CBIA terbukti dapat meningkatkan ketaatan dalam perawatan DM. CBIA-DM merupakan suatu kegiatan interaktif dalam pertukaran informasi dan mendiskusikan suatu topik, sehingga akan mengubah kebiasaan dan perilaku penderita DM (Hartayu et al, 2012). Hal ini dibuktikan dalam penelitian Hartayu, et al dimana CBIA-DM efektif dalam meningkatkan sikap, pengetahuan dan perilaku perawatan diri dari $40 \%$ menjadi $80 \%$. Penelitian lain juga menunjukkan bahwa CBIA-DM dapat meningkatkan kualitas hidup penderita DM (Arifin, 2018).

\section{TUJUAN}

Penelitian ini bertujuan untuk mengetahui Efektifitas DSME dan CBIA-DM terhadap tingkat Self Care pada Penderita Diabetes Mellitus.

\section{METODE}

Penelitian ini menggunakan desain penelitian quasy pre-post test design. Penelitian ini dilakukan di wilayah kerja Puskesmas Padangsari Banyumanik Semarang pada tanggal 20 Maret 2019 - 20 April 2019. Populasi pada penelitian adalah penderita diabetes mellitus di wilayah kerja Puskesmas Padangsari yaitu kelurahan Padangsari dan Pedalangan sebanyak 62 orang. Teknik sampling dengan non-probability sampling 
dengan purposive sampling berdasarkan rumus Lameshow didapatkan responden sebanyak 26 orang setiap kelompok.

Kriteria inklusi pada penelitian ini adalah berusia 30-65 tahun, pendidikan minimal SD, mampu melakukan aktivitas mandiri, memiliki kemampuan membaca yang baik skor self care < 32 (kategori self care buruk). Instrumen pada penelitian ini adalah kuesioner SDSCA oleh Kusniawati (2011), modul DSME oleh Kurniawati (2016) dan modul CBIA-DM oleh Sukmadewi (2015). Analisa data dengan menggunakan uji dependent $t$ test dan uji independent t test.

\section{HASIL}

\section{Karakteristik Responden}

Tabel 1 Karakteristik responden berdasarkan jenis kelamin, usia, tingkat pendidikan, pekerjaan, lama menderita, perilaku merokok $(n=52)$

\begin{tabular}{|c|c|c|c|c|}
\hline \multirow[t]{2}{*}{ Karakteristik } & \multicolumn{2}{|c|}{ Kelompok Intervensi DSME } & \multicolumn{2}{|c|}{ Kelompok Intervensi CBIA-DM } \\
\hline & $f$ & $\%$ & & $\%$ \\
\hline \multicolumn{5}{|l|}{ Jenis Kelamin } \\
\hline Laki-laki & 6 & 23,1 & 6 & 23,1 \\
\hline Perempuan & 20 & 76,9 & 20 & 76,9 \\
\hline \multicolumn{5}{|l|}{ Umur } \\
\hline Dewasa Awal (30-35) & 0 & 0 & 1 & 3,8 \\
\hline Dewasa Akhir (36-45) & 4 & 15,4 & 5 & 19,2 \\
\hline Lansia Awal (46-55) & 12 & 46,2 & 11 & 42,3 \\
\hline Lansia Akhir (56-65) & 10 & 38,5 & 9 & 34,6 \\
\hline \multicolumn{5}{|l|}{ Tingkat Pendidikan } \\
\hline Tamat SD/sederajat & 16 & 61,5 & 18 & 69,2 \\
\hline SLTP/sederajat & 7 & 26,9 & 5 & 19,2 \\
\hline SLTA/sederajat & 3 & 11,5 & 2 & 7,7 \\
\hline Perguruan Tinggi & 0 & 0 & 1 & 3,8 \\
\hline \multicolumn{5}{|l|}{ Pekerjaan } \\
\hline Tidak Bekerja & 12 & 46,2 & 11 & 42,3 \\
\hline Buruh & 5 & 19,2 & 7 & 26,9 \\
\hline Wiraswasta & 6 & 23,1 & 5 & 19,2 \\
\hline Pegawai swasta & 3 & 11,5 & 2 & 7,7 \\
\hline PNS & 0 & 0 & 1 & 3,8 \\
\hline \multicolumn{5}{|l|}{ Pendapatan } \\
\hline$\leq 2.300 .000$ & 21 & 80,8 & 23 & 88,5 \\
\hline$>2.300 .000$ & 5 & 19,2 & 3 & 11,5 \\
\hline \multicolumn{5}{|l|}{ Lama menderita } \\
\hline$<2$ tahun & 4 & 15,4 & 5 & 19,2 \\
\hline $3-5$ tahun & 11 & 42,3 & 10 & 38,5 \\
\hline$>5$ tahun & 11 & 42,3 & 11 & 42,3 \\
\hline \multicolumn{5}{|l|}{ Perilaku merokok } \\
\hline Merokok & 6 & 23,1 & 4 & 15,4 \\
\hline Tidak merokok & 20 & 76,9 & 22 & 84,6 \\
\hline
\end{tabular}

Berdasarkan tabel 1 yang mendeskripsikan mengenai karakteristik responden berdasarkan jenis kelamin, usia, pendidikan, pekerjaan, pendapatan, lama menderita dan perilaku merokok menunjukkan bahwa responden pada kedua kelompok didominasi oleh jenis kelamin perempuan, pada kelompok intervensi DSME dan CBIA-DM sebanyak 20 responden perempuan $(76,9 \%)$, usia responden yang paling banyak pada 
kedua kelompok adalah lansia awal (46-55 tahun) yaitu 12 responden (46,2\%) pada kelompok DSME dan 11 responden (42,3) pada kelompok CBIA-DM. Responden dengan tingkat pendidikan tamat SD/sederajat mendominasi kedua kelompok, 16 responden $(61,5 \%)$ kelompok DSME dan 18 responden $(69,2 \%)$. Sebagian besar kedua kelompok responden tidak bekerja yaitu 12 responden (46,2\%) kelompok DSME dan 11 responden $(42,3 \%)$ kelompok CBIA-DM. Tingkat pendapatan didominasi berada $\leq$ $2.300 .000,21$ responden $(80,8 \%)$ kelompok DSME dan 23 responden $(88,5 \%)$ kelompok CBIA-DM. Lama menderita responden berada pada rentang 3-5 tahun dan > 5 tahun dari masing-masing kelompok.

\section{Gambaran Self Care Sebelum dan Sesudah Intervensi DSME dan CBIA-DM}

Tabel 2 Gambaran self care pada kelompok DSME dan CBIA sebelum dan sesudah Intervensi $(n=52)$

\begin{tabular}{lccc}
\hline Kelompok & Sebelum & Sesudah & $\begin{array}{c}\text { Selisih } \\
\end{array}$ \\
\cline { 2 - 3 } & $\overline{\mathbf{x}} \pm \mathrm{SD}$ & $\overline{\mathbf{x}} \pm \mathrm{SD}$ & $\overline{\mathbf{x}} \pm \mathrm{SD}$ \\
\hline 1. DSME & $20,19 \pm 4,06$ & $38,69 \pm 6,90$ & $18,50 \pm 2,85$ \\
2. CBIA-DM & $20,62 \pm 4,21$ & $36,23 \pm 5,41$ & $15,61 \pm 1,21$ \\
\hline
\end{tabular}

Berdasarkan Tabel 2 diatas menunjukkan bahwa sebelum dilakukan intervensi DSME didapatkan rerata skor self care 20,19, sedangkan pada kelompok CBIA-DM sebelum intervensi rerata skor sebesar 20,62 dimana skor ini berada dalam kategori self care buruk. Sedangkan skor self care sesudah intervensi kelompok DSME sebesar 38,69 dan kelompok CBIA-DM sebesar 36,23 yang menunjukkan bahwa skor self care sudah meningkat menjadi kategori self care sedang.

\section{Pengaruh DSME dan CBIA-DM terhadap Self Care}

Tabel 3 Hasil analisa Dependent t test skor Self Care sebelum dan sesudah dilakukan DSME dan CBIA-DM $(n=52)$

\begin{tabular}{lccc}
\hline \multicolumn{1}{c}{ Kelompok } & Sebelum & Sesudah & \multirow{2}{*}{$p$ value } \\
\cline { 2 - 3 } & $\overline{\mathbf{x}} \pm \mathrm{SD}$ & $\overline{\mathbf{x}} \pm \mathrm{SD}$ & \\
\hline 1. DSME & $20,19 \pm 4,06$ & $38,69 \pm 6,90$ & 0,000 \\
2. CBIA-DM & $20,62 \pm 4,21$ & $36,23 \pm 5,41$ & 0,000 \\
\hline
\end{tabular}

Berdasarkan hasil uji dependent $t$ test yang terdapat pada tabel 3 bahwa kelompok DSME diperoleh nilai $p$ value $=0,000(<0,05)$ yang berarti bahwa ada pengaruh intervensi DSME terhadap self care yang digambarkan dengan adanya perbedaan yang 
signifikan pada skor self care sebelum dan sesudah dilakukan intervensi DSME. Sedangkan pada kelompok CBIA-DM diperoleh nilai $p$ value $=0,000(<0,05)$ yang berarti bahwa ada pengaruh tindakan CBIA-DM terhadap self care yang digambarkan dengan adanya perbedaan yang signifikan pada skor self care antara sebelum dan sesudah intervensi CBIA-DM.

\section{Efektivitas DSME dan CBIA-DM terhadap Self Care}

Tabel 4 Hasil analisis independent t test efektivitas DSME dan CBIA-DM terhadap self care

\begin{tabular}{cccc}
\hline Variabel & DSME & CBIA-DM & p value \\
\cline { 2 - 3 } & $\Delta \overline{\mathbf{x}} \pm \mathrm{SD}$ & $\Delta \overline{\mathbf{x}} \pm \mathrm{SD}$ & \\
\hline Self Care & $18,50 \pm 2,85$ & $15,61 \pm 1,210$ & 0,019 \\
\hline
\end{tabular}

Berdasarkan tabel 4 dari hasil uji Independet $t$ test menunjukkan bahwa dari kedua kelompok sebelum dan sesudah dilakukan intervensi sama-sama mempunyai perbedaan cukup signifikan yang ditunjukkan dengan nilai $p$ value 0,019 yang berarti $p<0,05$. Namun dari hasil tersebut dapat dilihat bahwa intervensi DSME merupakan kelompok yang lebih efektif terhadap self care dibandingkan dengan kelompok intervensi CBIADM yang ditunjukkan dengan $\Delta$ mean kelompok DSME sebesar 18,50 dan $\Delta$ mean kelompok CBIA-DM 15,61.

\section{PEMBAHASAN}

\section{Self Care Sebelum dan Sesudah Intervensi DSME}

Hasil penelitian yang telah dilakukan di wilayah kerja Puskesmas Padangsari Banyumanik Semarang seperti yang dapat dilihat pada tabel 3 menunjukkan bahwa tindakan DSME (Diabetes Self Management Education) berpengaruh terhadap self care dan terdapat kenaikan skor sesudah dilakukan tindakan.

Hal ini bisa dimungkinkan karena intervensi DSME akan menambah pengetahuan responden yang akan mendorong responden untuk melakukan self care lebih baik lagi. Hal ini didukung oleh hasil penelitian Powers et al (2015) yang menjelaskan bahwa DSME berperan penting untuk peningkatan pengetahuan, keterampilan dan kemampuan yang akan mengantarkan pada perilaku self care. Pemberian DSME dapat memberikan berbagai dampak dan hasil yang baik jangka pendek, menengah maupun jangka panjang, serta dapat memandirikan penderita dalam perawatan diri dan pencegahan komplikasi (Yuanita, 2014).

Penelitian lain yang mendukung penelitian ini adalah Bradshaw (2015) yang dilakukan di kota Kitts didapatkan terjadi peningkatan self care pada 15 responden dengan hasil $p$ value $0,001(\mathrm{p}<0,005)$ yang menunjukkan ada pengaruh DSME terhadap pengetahuan dan self care. Hal ini sejalan dengan hasil penelitian Indaryati (2018) dimana terdapat perbedaan rata-rata yang signifikan antara kelompok intervensi dan kontrol disemua 
perilaku self care baik diet, aktivitas fisik, penggunaan obat, monitoring gula darah dan mengurangi resiko kaki diabetes serta didapatkan $p$ value 0,000 .

Kelebihan Diabetes Self Management Education (DSME) adalah DSME mengintegrasikan lima pilar penatalaksanaan DM menekankan intervensi perilaku secara mandiri (Mandasari, 2017). DSME menggunakan metode pedoman, konseling, dan intervensi perilaku untuk meningkatkan pengetahuan mengenai diabetes dan meningkatkan keterampilan individu dan keluarga dalam mengelola penyakit (Sutandi, 2012). Pendekatan pendidikan kesehatan dengan metode DSME tidak hanya sekedar menggunakan metode baik langsung maupun tidak langsung namun telah berkembang dengan mendorong partisipasi dan kerjasama penderita diabetes dan keluarganya (Sutandi, 2012).

Metode DSME lebih efektif dalam meningkatkan skor self care pada perempuan daripada pada laki-laki. Hal ini ditunjukkan dengan rata-rata skor pada perempuan lebih tinggi yaitu sebesar 22,3 dan laki-laki sebesar 16,6. Perempuan lebih baik dalam hal belajar seperti membaca selain itu daya ingat perempuan lebih baik daripada laki-laki, selain itu perempuan lebih cepat belajar dan menerapkan hal yang dipelajarinya (Glasglow University, 2018). Hal ini sesuai dengan banyaknya topik yang ada dalam DSME justru pada laki-laki akan cepat bosan sedangkan pada perempuan akan lebih suka mempelajarinya (Glasglow University, 2018). Selain itu menurut Samuelsson (2016) laki-laki cenderung lebih menyukai pembelajaran dengan berkelompok, hal ini dapat membuat mereka lebih aktif dan mudah memahami pembelajaran.

\section{Self Care Sebelum dan Sesudah Intervensi CBIA-DM}

Penelitian yang telah dilakukan di wilayah kerja Puskesmas Padangsari Banyumanik Semarang seperti yang sudah ditampilkan pada tabel 4.3 yang dapat diartikan bahwa tindakan CBIA-DM (Community Based Interactive Approach Diabetes Mellitus) berpengaruh terhadap self care dan terdapat peningkatan setelah dilakukan tindakan.

Hal ini bisa terjadi karena pembelajaran aktif lebih cocok diterapkan pada orang dewasa Mayoritas usia responden pada kelompok CBIA-DM adalah 46-65 tahun yaitu lansia awal dan lansia akhir. Metode pembelajaran yang sesuai dengan prinsip-prinsip pendidikan orang dewasa yaitu motivasi (motivation), menarik perhatian diawal sesi (primacy), komunikasi dua arah (two way communication), umpan balik (feedback), belajar aktif (active leraning) (Arifin, 2018). Pembelajaran orang dewasa lebih efektif dilakukan pada kelompok kecil 5-6 orang dengan metode active learner participation (Dunst, 2016).

Sedangkan prinsip dari pelaksanaan CBIA-DM adalah active learning sehingga peserta dapat berdiskusi dan mengutarakan pendapatnya serta dapat melakukan tanya jawab yang dapat menggali lebih banyak informasi (Sukmadewi, 2015). Selain itu metode CBIA-DM mengembangkan cara berpikir kritis, analitis dan logis serta mengembangkan kerjasama, toleransi dan rasional (Saroh, 2015).

Hasil penelitian ini sejalan dengan hasil penelitian Hartayu et al (2012) dimana sikap, pengetahuan dan perilaku perawatan diri meningkat. Nilai pengetahuan meningkat dari 
$40 \%$ menjadi $80 \%$. Jumlah responden dalam kategori self care buruk juga berkurang dari $13,4 \%$ menjadi $6,6 \%$. Selain itu perilaku self care meningkat cukup signifikan yaitu dari $20 \%$ menjadi $46,6 \%$, dengan rata-rata skor self care sebelum intervensi adalah $33,5 \pm 4,1$ menjadi $34,9 \pm 6,2$, dengan nilai $p$ value 0,031 yang menunjukkan adanya pengaruh CBIA-DM terhadap self care.

Metode edukasi yang diterapkan akan mempengaruhi keberhasilan dalam pemberian informasi (Muhlisin, 2010). Pemberian informasi dimana satu orang yang aktif adalah semacam metode yang kurang kondusif untuk dieterapkan (Hartayu, 2012). Hal ini berbeda dengan metode CBIA-DM dimana peserta secara aktif mengikuti jalannya diskusi. CBIA pada prinsipnya melakukan pendekatan masalah dan menekankan proses belajar mandiri (Suryawati, 2010).

\section{Efektivitas DSME dan CBIA-DM terhadap Self Care}

Berdasarkan analisa data yang telah dilakukan menggunakan uji independent $t$ test diperoleh hasil rerata selisih self care pada kelompok DSME sebesar 18,50 dan rerata selisih self care pada kelompok CBIA-DM sebesar 15,62. Berdasarkan hasil tersebut dapat disimpulkan bahwa DSME memiliki rerata yang lebih besar daripada kelompok CBIA-DM . Hasil penelitian ini juga membuktikan bahwa DSME yang diberikan dapat meningkatkan perilaku self care responden.

Perbedaan hasil penelitian ini dikarenakan jumlah pertemuan pada intervensi DSME lebih sering dan topik yang diberikan lebih banyak. Semakin sering terpapar materi maka pengetahuan akan semakin meningkat (Yulia, 2015). Pengetahuan akan mempengaruhi perilaku kesehatan, apabila orang tersebut memiliki pengetahuan baik maka akan mendorong untuk melakukan perilaku kesehatan yang baik pula (Zhifei, 2016). Cara meningkatkan pengetahuan pasien adalah edukasi, dengan meningkatnya pengetahuan maka akan meningkat juga kesadaran diri dari segi kesehatan, merubah gaya hidup kearah sehat, patuh terhadap terapi dan hidup berkualitas (Wahid, 2016).

Meskipun CBIA-DM memiliki prinsip pembelajaran yang lebih cocok diterapkan untuk orang dewasa tetapi materi yang disampaikan tidak selengkap dan pertemuan yang dilakukan tidak sebanyak DSME, sehingga dimungkinkan informasi yang didiskusikan belum lengkap. Selain itu metode pembelajaran aktif juga tidak selalu berhasil diterapkan dan memberi hasil yang lebih baik daripada metode ceramah. Ardila (2014) yang menunjukkan bahwa tidak terdapat perbedaan efektivitas antara metode diskusi dengan metode ceramah dengan nilai $p$ value 0,102 . Hal ini sejalan dengan penelitian Hirawati (2014) yang juga menujukkan bahwa tidak ada perbedaan efektivitas metode diskusi dengan metode ceramah dengan nilai $p$ value 0,277 .

DSME adalah suatu metode yang berisi pendidikan kesehatan dimana didalamnya terdapat pengetahuan, keterampilan, kemampuan self care dan self efficacy yang bertujuan untuk mengelola penyakit DM (Rondhianto, 2012). Hal ini sejalan dengan teori self care Orem yang menjelaskan self care deficit terjadi jika self care agency tidak dapat memenuhi atau lebih rendah dari self care demands, dan self care agency dapat dipengaruhi oleh diantaranya status kesehatan dan pengetahuan. Self care deficit lebih sering terjadi pada perempuan daripada laki-laki dikarenakan perempuan lebih peduli 
dengan kesehatannya dan lebih disiplin dalam melakukan perilaku self care (Putri, 2017). Metode untuk mengatasinya adalah dengan pendidikan dimana perempuan juga lebih baik dalam hal belajar daripada pada laki-laki yang biasanya lebih cepat bosan (Glasglow University, 2018). Hal itu yang menyebabkan lebih tingginya kejadian self care deficit pada laki-laki daripada perempuan.

DSME dilakukan dalam 4 sesi dengan durasi 1-2 jam persesi (Central Dupage Hospital, 2011), dengan topik pemahaman tentang penyakit, pengertian etiologi, klasifikasi, patofisiologi, manifestasi klinis, penatalaksanaan, pengaturan makan atau diet, perawatan kaki dan monitoring gula darah, terapi farmakologis, manajemen stress, dukungan psikososial, hipoglikemia dan Hiperglikemia, akses ke pelayanan kesehatan (Funnel, 2008; Stanford School of Medicine, 2016; Central Dupage Hospital, 2011).

\section{SIMPULAN DAN SARAN \\ Simpulan}

DSME dan CBIA-DM dapat meningkatkan self care pada pasien diabetes mellitus. Sedangkan pada analisa uji independent $t$ test didapatkan $p$ value 0,019 yang berarti terdapat perbedaan yang cukup signifikan antara kedua kelompok, dan hasil $\Delta$ mean kelompok DSME 18,50 dan $\Delta$ mean kelompok CBIA-DM 15,61, sehingga DSME lebih efektif dibandingkan CBIA-DM.

\section{Saran}

Puskesmas dapat menerapkan Diabetes Self Management Education (DSME) karena terbukti lebih efektif dalam meningkatkan self care dengan cara melakukan sosialisasi dan penyuluhan melalui kegiatan prolanis di Puskesmas tersebut sesuai dengan SOP, sehingga dapat menambah pengetahuan penderita diabetes mellitus serta dapat meningkatkan perilaku self care untuk mencegah komplikasi dan meningkatkan kualitas hidup penderita.

Penelitian selanjutnya dapat menyertakan kelompok kontrol dan menerapkan family care center dalam mengedukasi self care untuk hasil yang lebih maksimal. Selain itu diharapkan peneliti selanjutnya dapat meningkatkan keaktifan peserta dalam pelaksanaan intervensi CBIA-DM dengan memberikan motivasi dan menumbuhkan minat responden terhadap jalannya diskusi dengan mempertimbangkan latar belakang pendidikan dan budaya.

\section{REFERENSI}

Ardila, A., Ridha, A., \& Jauhari, A.H., (2014). Efektivitas metode diskusi kelompok dan ceramah dalam meningkatkan pengetahuan, (online), (www.jurnalmahasiswa_peneliti.kesehatan.ac.id, diakses tanggal 28 April 2019).

Arifin., \& Bustanul., (2018). Distress and health related quality of life in Indonesian type 2 diabetes mellitus outpatients, (online), (https://www.rug.nl-file-chapter1, diakses tanggal 1 Desember 2018).

Bradshaw, R.D. (2015). Diabetes Self Management Education for Adults with Type 2 Diabetes Mellitus. Disertasi tidak dipublikasikan. Program Studi Ilmu Kedokteran, Walden University. 
Dunst, C.J., Trivette, C.M., \& Deborah, W.H., (2010). Meta-analysis of effectiveness of four adult learning methods and strategies, (online), Vol.3, No.1, (www.puckett.org, 24 Mei 2019).

Funnel, M.M., et al. (2008). National Standards for Diabetes Self Management Education. Diabetes Care Volume 31 Supplement 1.

Hartayu, T.S., Izham, M., \& Suryawati, S, (2012). Improving of Type 2 Diabetic Patients Knowledge Attitude and Practice towards Diabetes Sel-care by implementing Community-Based Interactive Approach-Diabeets Mellitus Strategy. BMJ Research Notes, (online), Vol.5, (http:www.biomedcentral.com/1756-0500/5/315, diakses tanggal 28 November 2018).

Hirawati, H., Masruroh, \& Triwijayanti, W.O., (2014). Pengaruh pendidikan kesehatan menggunakan metode ceramah dan diskusi kelompok terhadap peningkatan pengetahuan, (online), Vol.2, No.2, (jurnalkeperawatanmaternitas-journalarticle-download, diakses tanggal 18 April 2019).

Indaryati, S., (2018). Pengaruh Diabetes Self Management Education (DSME) terhadap self care pasien Diabetes Mellitus RS Kota Palembang, (online), Vol.1, No.1, (http://ojs.ukmc.ac.id/index.php/JOH, diakses tanggal 14 November 2018).

Karimi, F., Abedini, S., \& Mohseni, S., (2017). Self-care behavior of type 2 diabetes mellitus patients in Bandar Abbas in 2015, (online), Vol.9, No.11, (http://www.ephysician.ir, diakses tanggal 4 November 2018).

Kurniawati, T. (2016). Modul Diabetes Self Management Education (DSME) Edukasi Manajemen Diri pada Diabetes. Yogyakarta: Program Studi Magister Keperawatan.

Kusniawati. (2011). Analisis Faktor yang berkontribusi terhadap self care diabetes pada klien diabetes mellitus tipe 2 di Rumah Sakit Umum Tangerang. Tesis tidak dipublikasikan. Depok: Program Magister Keperawatan, Fakultas Ilmu Keperawatan.

Lathifah, M.A., Susanti, Ilham,M., \& Wibowo, A., (2015). Perbandingan Metode CBIA dan FGD dalam peningkatan Pengetahuan dan Ketepatan Caregiver dalam Upaya Swamedikasi Demam Pada Anak, (online), Vol.2, No.2, (psr.ui.ac.idjournal-article-download, diakses tanggal 28 November 2018).

Powers et al., (2015). Diabetes Self-management Education and Support in Type 2 Diabetes : A join position statement of the American Diabetes Association, the American Association of Diabetes Educators, and the academy of nutrition and dietetics, (online), (care.diabetesjournals.org/content/early/2015/06/02/dc150730, diakses tanggal 10 November 2018).

Prihaningtyas, R.A. (2013). Hidup Manis dengan Diabetes. Yogyakarta: Media Pressindo.

Putri, N.H.K.,, M.A., (2017). Hubungan empat pilar DM Tipe 2 dengan rerata kadar gula darah, (online), Vol.1, No.2, (journal.unair.ac.id-filerPDF, diakses tanggal 22 November 2018).

Rahmawati., Tahlil, T., \& Syahrul., (2016). Pengaruh Program Diabetes SelfManagement Education terhadap Manajemen Diri Pada Penderita Diabetes Mellitus Tipe 2, (online), Vol.4, No.1, (www.jurnal.unsyiah.ac.id, diakses tanggal 18 Oktober 2018). 
Raithatha, S.J., Shankar, S.U., \& Dinesh, K., (2014). Self-Care Practices among Diabetic Patients In Anand District Of Gujarat, (online), (http://dx.doi.org/10.1155/2014/743791, diakses tanggal 1 November 2018).

Rondhianto., (2012). Keterkaitan Diabetes Self Management Education Terhadap Self Efficacy Pasien Diabetes Mellitus, (online), (download.portalgaruda.org, diakses tanggal 10 Oktober 2018).

Samuelsson, M., \& Samuelsson, J., (2016). Gender differences in boy's and girls's perception of teaching and learning, (online). Vol.3, No.1, (https://www.tandfonline.com, 24 Mei 2019).

Saroh, M.T. (2015). Pelaksanaan Metode Ceramah dan Diskusi Kelompok dalam Meningkatkan Efektivitas Pembelajaran. Skripsi tidak dipublikasikan, Universitas Islam Negeri Maulana Malik Ibrahim : Malang.

Shrivastava, S.R., Shrivastava, P.S., \& Ramasamy, J., (2013). Role of self-care in management of diabetes mellitus, (online), Vol.12 No.14, (https://www.jdmonline.com/content/12/1/14, diakses tanggal 16 Oktober 2018)

Stanford Patient Education Research Center. (2016). Better choices Better healthDiabetes or Healthier Living with Diabetes (Internet Diabetes Self-Management Program). (online), (http://patienteducation.standford.edu/internet/diabeteso.html, diakses tanggal 22 November 2018).

Suhanda, Y., Afgani, A., \& Feriandi, Y., (2015). Gambaran Tingkat Self Care Pada Pasien Rawat Jalan Diabetes Mellitus Tipe 2 di RSUD Al-Ihsan Provinsi Jawa Barat, (online), Vol.2, (karyailmiah.unisba.ac.id, diakses tanggal 16 Oktober 2018).

Sukmadewi. (2015). Peningkatan pengetahuan, sikap dan tindakan pria usia lanjut di kecamatan Tegalrejo Kota Yogyakarta tentang diabetes mellitus dengan metode CBIA. Skripsi tidak dipublikasikan. Yogyakarta: Program Studi Farmasi, Fakultas Farmasi.

Suryawati, S., (2010). CBIA : "Cara Belajar Ibu Aktif” a Community-based Interactive Approach toeard safe, effective, cost-efficient self-medication, Melati Nusantara Foundation, Yogyakarta, 67-69.

Wahid, R.A.N. (2016). Pengaruh Pendidikan Kesehatan Diabetes Self Management Education (DSME) terhadap Kadar Gula Darah Pasien Diabetes Tipe II di Prolanis Puskesmas Gajahan Surakarta. Skripsi tidak dipublikasikan. Surakarta: Program Studi S-1 Keperawatan Stikes Kusuma Husada.

Yuanita, A., Wantiyah., \& Susanto, T., (2013). Pengaruh Diabetes Self Management Education (DSME) terhadap Resiko Terjadinya Ulkus Diabetik pada Pasien Rawat Jalan dengan Diabetes Mellitus (DM) Tipe 2 di RSD dr. Soebandi Jember, (online), Vol.2, No.1, (repository.unej.ac.id, diakses tanggal 12 November 2018).

Zandinava, H et al., (2017). Effect of Educational Package of Self-care behaviors, Quality of Life, and Blood Glucose Levels in Pregnant Women with Gestational Diabetes : A Randomized Controlled Trial, (online), Vol.19, No.4, (https://www.researchgate.net, diakses tanggal 4 November 2018).

Zhifei et al., (2016). Factors Influencing Healt Knowledge and Behaviors among the Elderly in Rural China, (online), Vol.13, (www.mdpi.com/journal/ijerph, $24 \mathrm{Mei}$ 2019). 